\title{
The quality of early childhood education and care services in Greece
}

\author{
Christina Megalonidou*
}

\author{
${ }^{*}$ Correspondence: \\ megaloni@bc.teithe.gr \\ Dept. of Early Childhood Care \\ \& Education, International \\ Hellenic University, \\ P.O. Box 141, Sindos, \\ 57400 Thessaloniki, Greece
}

\begin{abstract}
High-quality early education and care experiences are critical for children's growth and development, families' ability to work, and the future health of society. In Greece, with regard to research for children under 3 years of age in early childhood education and care services, the issue of quality has been only marginally researched. The lack of available information on the quality of childcare services has been widely documented. The purpose of this study was to investigate the quality of early childhood education and care services in North Greece. Nonprofit and for-profit centers (one hundred and thirtyone classrooms) for children under 3 participated in this study. For quality assessment, we used the ITERS-R scale (Infant/Toddler Environment Rating Scale-Revised). Results suggested the existence of mediocre average quality.
\end{abstract}

Keywords: Early childhood education and care services, Quality, Children under 3, ITERS-R, North Greece

\section{Introduction}

In Greece, early childhood education and care services (ECEC) for children under 3 are represented only by "daycare centers/nurseries or crèche." The daycare centers are run by the private (for-profit) and public (through municipalities for profit and nonprofit) sector. Municipalities' daycare centers come under the auspices of the Ministry of Interior and admit children from the age of 6 months up to $2 \frac{1}{2}$ years. The Ministry of Labor, Social Security and Social Solidarity is mainly responsible for the private daycare centers and admits children from the age of 2 months up to $2 \frac{1}{2}$ years. Municipal Daycare centers operated either by a municipal legal entity (nonprofit) or by a municipal utility enterprise or in the context of a respective municipal service (for-profit). Priority for registration is given to children of working parents, of unemployed parents, of economically disadvantaged families are selected in the registration procedure (such as orphans, double orphans, children coming from single parent families, children of divorced or separated parents, children of women accommodated in the network of structures protecting women who experienced violence, children coming from families that have family members with physical or mental disabilities, children coming from large families, etc.) by nonprofit centers and have monthly fees according to social criteria. For example

\footnotetext{
The terms "nursery", "crèche", and "day care center" are used as synonymous concerning the early childhood education and care services for children under 3 in Greece.

(c) The Author(s) 2020. This article is licensed under a Creative Commons Attribution 4.0 International License, which permits use, sharing, adaptation, distribution and reproduction in any medium or format, as long as you give appropriate credit to the original author(s) and the source, provide a link to the Creative Commons licence, and indicate if changes were made. The images or other third party material in this article are included in the article's Creative Commons licence, unless indicated otherwise in a credit line to the material. If material is not included in the article's Creative Commons licence and your intended use is not permitted by statutory regulation or exceeds the permitted use, you will need to obtain permission directly from the copyright holder. To view a copy of this licence, visit http://creativeco
} mmons.org/licenses/by/4.0/ 
fees can be zero, for those who have an annual income of less than $€ 15.000$. Fees in private and municipal daycare centers for profit are significantly higher.

In recent decades, early childhood education and care services (ECEC) for children under 3 have become a matter of serious public concern. Affordable and good-quality daycare services may improve the reconciliation of work and family life and thus foster labor market participation and gender equality. Daycare facilities may also provide an important answer to declining fertility rates, by lowering the cost of childbearing in terms of labor market and career opportunities. Finally, there is a growing tendency to see daycare services from a social pedagogical perspective. In this perspective, the main policy rational is no longer the reconciliation of work and care, but rather the contribution of daycare services to child development and socioeconomic integration (European Commission 2014).

The level of quality in daycare centers has been shown to have significant implications for children's immediate and long-term development. Current research suggests that the quality of childcare during the first 3 years of life can impact cognitive skills, language, school readiness, social and emotional development, and resiliency to life stress (Burchinal et al. 1996, 2006; Burchinal 2016; Melhuish et al. 2015; Howes 1997; Dunn 1993; Vandell and Wolfe 2000a; OECD 2017; Plantenga and Remery 2009), especially for children from disadvantaged family backgrounds and "at risk" (Arnold and Doctoroff 2003; Campbell et al. 2008; Bardige 2006; Melhuish 2001; Dearing et al. 2009; von Suchodoletz et al. 2017) with some documented benefits into adolescence and early adulthood (Harvard Center 2010, Vandell et al. 2010). Concerns over detrimental effects of spending a large number of hours in daycare centers have also been raised with regard to children's behavioral regulation, but recent evidence from Norway indicates no association between quantity of care and behavior problems (Zachrisson et al. 2013).

These results highlight the need to assess and enhance the quality of daycare centers. There is broad acceptance that quality in childcare services can be addressed by examining two commonly accepted components-structure and process (Howes and Rubenstein, 1983; Penn 2011; Phillipsen et al. 1997; Beller et al. 1996). Structural quality refers to components such as physical environment (buildings, space and materials), childstaff ratios, staff education and training, and curriculum that are more easily measurable in determining quality (Barros et al. 2016; Slot et al. 2015; OECD 2006). Process quality focuses on the nature of interactions between the children and teachers, among children, and among adults - teachers, parents, staff, and on the nature of leadership and pedagogy (Barros et al. 2016; Slot 2017; Thomason and La Paro 2009; Vandell and Wolfe 2000a; Cryer 1999; Goelman et al. 2006). The Infant/Toddler Environmental Rating Scale-Revised Edition (ITERS-R; Harms et al. 2006) is a widely used instrument in research on childcare quality (Barros et al. 2016; Bjørnestad and Os 2018; Baustad 2012; Campbell et al. 2008; Gevers Deynoot-Schaub and Riksen-Walraven 2008; Goelman et al. 2006; Vermeer et al. 2016). The instrument assesses overall or global quality of the classroom environment for children up to 30 months of age.

Despite research indicating positive developmental outcomes for children receiving high-quality care and increasing numbers of young children in out-of-home care, daycare centers are often plagued with poor structural and process quality, and the least prepared and lowest compensated workforce (OECD 2015; Burchinal et al. 1996; 
Whitebook et al. 1989; Ghazvini and Mullis, 2002; Goelman et al. 2006; Helburn 1995, Helburn and Howes 1996; Howes et al. 1988.

In many European countries, the level of quality of services for children under 3 gives rise for concern. There are two main forms of ECEC structure in Europe: the split and unitary model, reflecting the attitudes and perceptions of preschool age in each country. In a split model, ECEC provision is structured according to the age of children; often one system is set up for children $0-3$ of age, primarily focusing on care provision. The other system focuses at older children 3-6 of age and the emphasis lies primarily on education and preschool preparation. The responsibilities for governance, regulation and funding are divided into two or more ministries, between the ministry for health, welfare or family for younger children, while the ministry of education is responsible for the older children. Consequently, educational guidelines normally apply only to provision for older children. Also, the requirements for staff qualifications differ, with tertiary degrees in ECEC required mostly in settings for older children. Moreover, access may vary with a legal entitlement usually applying to older children. In a unitary model, ECEC is organized in a single phase for all children of preschool age. Often, children go to one institution, governed by one specific ministry, led by one management team for children of all age groups, and the ECEC practitioners generally have similar qualifications and pay level in all groups of children. The universal right to access from the youngest age is clearly recognized in countries that have the unitary model. The unitary model seems to provide better consistency between care mechanisms and the rest of the education system, more resources for children under the age of 3, universal access to all ages and better staff training (Nordic countries as well as in several Baltic and Balkan countries). Split system for ECEC is still common in most European countries ..$^{2}$ In seven countries, both unitary and separate settings co-exist (Bulgaria, Denmark, Germany, Estonia, Spain, Austria and the United Kingdom) (Eurydice and Eurostat Report 2014, 2019). The OECD has already indicated in its Starting Strong studies how the separation of 'education' and 'care' in some cases may undermine the delivery of quality ECEC (OECD 2006). The current concerns about the quality of care provided to younger children are corroborated by surveys conducted in European context. Vermeer et al. (2008) used the ITERS-R scale to assess the quality of childcare in a representative national sample of 42 childcare centers in the Netherlands. The total number of childcare groups in the 42 centers was $153(\mathrm{M}=3.6 ; \mathrm{SD}=1.90)$ per center. The average overall quality score on the ITERS was 3.4 (minimal level). Similarly, Tietze and Cryer (2004) used the ITERS to measure the quality of 75 childcare centers in East and West Germany. The average overall quality score was 3.2. In 2011, again a nationwide quality research project was funded, called the NUBBEK study (National Inquiry on Early Child Care and Education), showed that less than $10 \%$ of the early childcare centers reached good or excellent quality (Tietze et al. 2013). In England, 75 childcare centers assessed using the same quality measure were found to have mean score 4.2 (Smith et al. 2009). Three studies in Portugal reported poor-quality care and education. Barros and Aguiar (2010) assessed the quality

\footnotetext{
${ }^{2}$ In ECEC systems with separate settings, the transition between the two different types of setting usually takes place at the age of 3. It may happen at an earlier age (2-and-a-half in Belgium-French and Flemish Communities) or at a later age (4 in Greece, the Netherlands, Switzerland and Liechtenstein).
} 
of 160 toddler childcare classrooms in the district of Porto. The average quality score on ITERS-R scale was 2.84. Pessanha et al. (2007) assessed the quality of 15 infant centers in Porto. One hundred and twelve infants between 1 and 3 years of age participated in this study. The average quality score on ITERS-R scale was 2.6. Finally, Pinto et al. (2013) assessed the quality of 95 infant classrooms in Porto and found that the overall mean result on ITERS-R was 2.5. In Norway, the childcare centers were found to have high quality scores. The average quality score on ITERS-R scale was 5.4 ranged between good and excellent (Baustad 2012).

Greece has two types of institutions: kindergartens (nipiagogeio) and childcare centers. Children aged 4 and 5 attend pre-primary school (nipiagogeio), which falls under the responsibility of the Ministry of Education, Research and Religious Affairs. Since 2018/19, the start of compulsory education (pre-primary school/nipiagogeio) has been lowered from age 5 to 4 . All kindergartens follow a national curriculum and only university graduates can be hired as educators. Public childcare centers accept children from 6 months to 4 years of age. More specifically, daycare centers/nurseries or crèche provide services for children from 6 months to 2-and-a-half years (vrefikos stathmos), for children aged 2 months to 4 years, with infant-toddler classrooms and classrooms with children from 2-and-a-half to 4 years (vrefonipiakos stathmos) and child centers for children aged from 2-and-a-half to 4 years (paidikos stathmos). Until 2001, public childcare centers were under the auspices of the Ministry of Health and Welfare. Since then, they are funded and supervised by the municipalities with support of the Ministry of Interior. As mentioned above there is no universal right to access. Also, there is no national curriculum. The OECD has already indicated in its Starting Strong studies how the separation of 'education' and 'care' in some cases may undermine the delivery of quality ECEC (OECD 2006). Indeed, if a country considers childhood as an important and formative stage of life, childcare and early education are more often integrated in one system, which contributes to clearer objectives for ECEC providers, parents and other stakeholders.

In Greece, with regard to research for children under 3 years of age in ECEC, the issue of quality has been only marginally researched. The lack of discussion about quality, combined with the absence of official evaluation procedures, has as result given a very limited picture of the quality of child care services (Petrogiannis 2013). The relevant research remains an underdeveloped area receiving neither adequate encouragement nor support. What we know about the quality of Greece daycare services comes from the work of individual researchers. Older studies show a low to medium level of overall quality, especially in indicators like learning and teaching, style of care, building and equipment, adult-child ratios and family-educators relationships (Petrogiannis 2013; Rentzou 2015).

Therefore, the main goal of this study was to describe the quality of infants' childcare classrooms in the North Greece.

\section{Method}

\section{Participants and setting}

The research was carried in daycare centers in Northern Greece. The term "Northern Greece" is widely used to refer to regions of Macedonia and Thrace. It is the second 
largest geographical division in Greece by population, after Continental Greece (about 2.38 million in 2017). Thessaloniki is the second largest city in Greece, with over 1 million inhabitants in its metropolitan area, and the capital of the Northern Greece.

For the selection of registered private and municipal daycare centers in Northern Greece, the official list was taken from Welfare Offices of each prefecture. The list of municipal daycare centers was retrieved from each municipality as there was no official list in Ministry of Interior. The total number of all officially authorized daycare classrooms with children under 3-year old in Northern Greece was 131, from 103 daycare centers.

The sample of our study included all 131 daycare classrooms with children under 3 -year old. Of those, 98 were in Thessaloniki and 33 in the country. Of those, 46 were municipal daycare classrooms, 12 were municipal daycare classrooms for profit and 73 were privately owned. 28 of the 46 municipal daycare classrooms were in Thessaloniki and 18 in the country. From the 12 municipal daycare classrooms for profit, 11 were located in Thessaloniki and 1 in the country. Finally, from the 73 private daycare classrooms 59 were in Thessaloniki and 14 in the country. In the total of 131 daycare classrooms 2033 infants were accommodated. 563 of them were in municipal daycare classrooms, 120 in municipal daycare classrooms for profit and 1027 were privately owned.

\section{Instruments}

The Infant-Toddler Environmental Rating Scale Revised Edition (ITERS-R; Harms et al. 2006) was used to measure the global quality of the individual classrooms serving children from birth through 30 months of age. First, the scale was translated by two independent translators from English into Greek. The translators were fluent speakers of both languages, were qualified early childhood educators and had knowledge of the scale. Then, the research team (the two trained observers) reviewed both versions of translations and resulted in a common format translation. This translation was once again reviewed by a third person fluent in both languages, held a degree in early childhood education and had knowledge of the scale (author). The last translated version was the one was applied. The ITERS-R includes 39 items, organized under 7 subscales: I. Space and Furnishings (5 items); Personal Care Routines for infants and toddlers (6 items); Listening and Talking (3 items); Age Appropriate Activities (10 items); Adult-Child Interaction ( 4 items); Program Structure (4 items); and Parent and Staff Communication (7 items). The scale is designed to be used with one room or one group at a time. A block of at least $3 \mathrm{~h}$ should be set aside for observation and rating. Also the observer should arrange a time with the teacher to ask questions about indicators that were not able to observe. Approximately 20-30 min will be required for questions (Harms et al. 2006). Observers rated individual classrooms using a 7-point scale for 39 total items during a 3-h observation period, with descriptors for 1 (inadequate), 3 (minimal), 5 (good), and 7 (excellent). Internal consistency has a Cronbach's alpha $=.76$ for the complete scale. Space and Furnishings includes aspects of the environment, such as indoor space, furniture and display for children. Personal Care Routines encompass aspects of daily routines, such as nap, meals, health and safety practices. Listening and Talking includes 
a focus on language and books used in the classroom. Activities include children's engagement in play, fine motor, science, and music activities. Interaction includes supervision, peer and staff-child interactions. The Program Structure includes free and group play activities, provisions for children with disabilities and finally Parents and Staff subscale includes provisions for parents and needs of staff.

\section{Procedure}

\section{Observer training}

Training for all of the scales included detailed information on each measure as well as Video Guide and Training Workbook for the ITERS-R and practice classroom observations. An expert researcher (author) trained two observers in the ITERS-R. The three observers conducted training sessions in 19 daycare classrooms, aiming at $80 \%$ interrater agreement. The mean interrater percent agreement for these classrooms was $89 \%$.

\section{Data collection}

All data were collected by two researchers. As suggested by scale authors, each observer remained with each group of children at least $3 \mathrm{~h}$ to observe classroom main routines and activities. All classrooms were observed during the morning, the period of greatest activity among infant care classrooms. At the end of each observation, a teacher meeting was used to clarify demographic information and to complete the items that could not be observed. Meetings lasted approximately $30 \mathrm{~min}$. In addition to completing the ITERS-R, observers also collected background information on teachers, group size, and teacher/child ratios during their observation.

Inter-observer agreement checks were conducted during the data collect procedure, across 34 agreement sessions. Interrater exact percent agreement, $M=94.37$.

\section{Results}

The observations and the interviews by ITERS-R (Harms et al. 2006) were carried out based on the directions given in ITERS-R. No elements in the scales were changed or left out, except item 23 (Use of TV, video, and/or computer) and item 32 (Provisions for children with disabilities) because it were scored as "Not applicable".

Overall mean results ranged from 2.60 to $5.40(\mathrm{M}=3.88, \mathrm{SD}=.70)$, presenting a normal distribution. In general, the quality of the daycare centers' ranged between minimum (3) and good (5) and suggested the existence of mediocre average quality.

Table 1 presents descriptive statistics for ITERS-R subscales and items. Mean subscales scores varied between 2.91 (Program structure) and 5.56 (Interaction). Five of the seven subscales presented mean scores between minimum (3) and good (5). The subscale 'Interaction' (item 25-28) was the subscale with an overall average high score (between good and excellent) while the subscale "Program structure" (item 29-32) was the subscale with lower score.

Mean results at the item level ranged from 1.42 (Nature/science) to 6.39 (Staff continuity). Highest average scores are achieved for items 36 "Staff interaction and cooperation" and 37 "Staff continuity" (almost excellent quality), items 11 "Safety practices", 15 "Fine Motor", 25 "Supervision of play and learning", 26 "Peer interaction", 27 "Staffchild interaction", 25 "Supervision of play and learning", 26 "Peer interaction" and 27 
Table 1 Descriptive Statistics for ITERS-R Items and Subscales

\begin{tabular}{|c|c|c|c|}
\hline & Mean & SD & Min/Max \\
\hline I. Space and Furnishings & 4.31 & 1.28 & $0.6-6.6$ \\
\hline 1. Indoor space & 4.78 & 2.19 & $0-7$ \\
\hline 2. Furniture for routine care and play & 3.97 & 2.20 & $0-7$ \\
\hline 3. Provision for relaxation and comfort & 4.51 & 1.75 & $0-7$ \\
\hline 4. Room arrangement & 4.25 & 1.89 & $0-7$ \\
\hline 5. Display for children & 4.02 & .94 & $2-7$ \\
\hline II. Personal Care Routines & 3.89 & 1.08 & $1.5-6.5$ \\
\hline 6. Greeting/departing & 2.32 & 1.18 & $0-6$ \\
\hline 7. Meals/snacks & 4.47 & 1.58 & $0-7$ \\
\hline 8. Nap & 4.55 & 1.94 & $0-7$ \\
\hline 9. Diapering/toileting & 2.69 & 1.97 & $0-7$ \\
\hline 10. Health practices & 3.40 & 1.96 & $0-7$ \\
\hline 11. Safety practices & 5.89 & 1.34 & $1-7$ \\
\hline III. Listening and Talking & 3.98 & 1.25 & $0-7$ \\
\hline 12. Helping children understand language & 4.55 & 1.62 & $0-7$ \\
\hline 13. Helping children use language & 4.21 & 1.60 & $0-7$ \\
\hline 14. Using books & 3.18 & 1.67 & $0-7$ \\
\hline IV. Activities & 3.21 & 0.92 & $1.3-5.2$ \\
\hline 15. Fine motor & 5.25 & 1.56 & $0-7$ \\
\hline 16. Active physical play & 2.27 & 1.71 & $0-7$ \\
\hline 17. Art & 2.66 & 1.30 & $0-7$ \\
\hline 18. Music and movement & 4.54 & 1.67 & $0-7$ \\
\hline 19. Blocks & 4.94 & 1.85 & $0-7$ \\
\hline 20. Dramatic play & 4.52 & 1.38 & $1-7$ \\
\hline 22. Nature/science & 1.42 & 1.23 & $0-7$ \\
\hline 24. Promoting acceptance of diversity & 1.98 & 1.85 & $0-7$ \\
\hline V. Interaction & 5.56 & 1.28 & $2.5-7$ \\
\hline 25. Supervision of play and learning & 5.97 & 1.44 & $2-7$ \\
\hline 26. Peer interaction & 5.66 & 1.31 & $0-7$ \\
\hline 27. Staff-child interaction & 5.73 & 1.75 & $0-7$ \\
\hline 28. Discipline & 4.89 & 1.91 & $0-7$ \\
\hline VI. Program Structure & 2.91 & 1.04 & $1-7$ \\
\hline 29. Schedule & 3.29 & 1.56 & $1-7$ \\
\hline 30. Free play & 2.64 & 1.45 & $1-7$ \\
\hline 31. Group play activities & 3.07 & 1.71 & $0-7$ \\
\hline VII. Parents and Staff & 3.76 & 0.92 & $2.3-6.1$ \\
\hline 33. Provisions for parents & 1.63 & 1.56 & $0-7$ \\
\hline 34. Provisions for personal needs of staff & 3.62 & 2.26 & $0-7$ \\
\hline 35. Provisions for professional needs of staff & 3.81 & 2.51 & $0-7$ \\
\hline 36. Staff interaction and cooperation & 6.27 & 1.29 & $0-7$ \\
\hline 37. Staff continuity & 6.39 & 1.63 & $0-7$ \\
\hline 38. Supervision and evaluation of staff & 2.84 & 1.00 & $0-7$ \\
\hline 39. Opportunities for professional growth & 1.82 & 1.46 & $0-7$ \\
\hline Overall subscale & 3.88 & 0.70 & $2.6-5.4$ \\
\hline
\end{tabular}

"Staff-child interaction" (between good and excellent quality). Lowest average scores are achieved for items 24 "Promoting acceptance of diversity", 33 "Provisions for parents" and 38 "Supervision and evaluation of staff" (inadequate quality). 


\section{Discussion}

Results from this study suggest that all 131 daycare classrooms with children under 3 -year old in Northern Greece qualifying for mediocre average quality. Five of the seven subscales presented mean scores between minimum (3) and good (5) while the subscales "Program structure" (item 29-32) and "Activities" (item 15-24) were the subscales with lower score. These findings support results previously reported by Petrogiannis (2002) using the ITERS $(M=3.50)$ and Rentzou (2011) using the ITERS-R $(M=3.23)$; none of the childcare centers assessed were found to have high quality scores, but ranged between minimal and good.

The average quality score on subscale Space and Furnishings was medium. In Greece, a study of the Athens Municipal Crèche's (AMC) settings showed that the majority of buildings were free of technical or operational issues. However, none of the 77 settings has the required (by 2002 law) license to operate; something that is encountered in other cities as well, suggesting that some of these buildings could have been built for other purposes but later were modified to nurseries to cover the local needs for daycare provision. The medium scores for space and furnishing could be attributed to economic reasons because settings rely on local authorities to subsidize them. Recently, this situation has been changed by the Ministerial Decision 41087/29-11-2017 "Standard Regulation of Operation for Municipal Child and Infant/Child Centers". This decision is setting out the conditions for the establishment and operation of childcare centers operating within the legal entities of municipalities or within municipal units and also of private childcare centers, the relevant technical specifications, the specific terms and conditions of suitability as well as the control. Since 2019, daycare centers that did not meet the above regulations were forced to suspend their operation.

Program structure $(M=3.21)$ and Activities $(M=2.91)$ were the subscales with lower score. Previous research findings have also identified low scores for the two particular subscales (Petrogiannis 2002; Rentzou 2011). Although a number of European member states have recently initiated reforms, in Greece early childhood education and care (ECEC) is not only still provided in separate settings: kindergartens and infant/childcare centers but furthermore have become more split. Kindergartens provide education for children 4 to 6 . Since 2006, attendance has become compulsory for children 5- to 6-year old and more recently for children 4- to 5-year old. Kindergartens are supervised and regulated by the Ministry of Education and follow a national preschool curriculum developed by the Institute of Educational Policy. This curriculum describes the purpose of kindergartens, the learning outcomes and areas and is accompanied by an educator guide. Public childcare services for infant and toddler accept children from 6 months to $2 \frac{1}{2}$ years. They are run, funded and supervised by local authorities with the support of the Ministry of Interior. Private services are supervised by the Ministry of Health and Social Welfare. Children with working parents, families with low economic resources and children who need special care have priority. There is no national curriculum but operation standards mainly refer to nursery facilities' safety features, staff employed (tasks and qualifications), structural features such as child-staff ratios (1 educator and 1 assistant to 8 , or 2 educators and 1 assistant to 12 , infants or toddlers), hygiene conditions and feeding arrangements. Low scores on such subscales may place children at increased risk of infections and limit children's opportunities to develop language and 
literacy skills, critical scientific reasoning and positive attitudes toward diversity. Reasons for this lack of developmental appropriateness may be due to a custodial conceptualization of infant and toddler care, opposed to an educational focus (Petrogiannis 2013). One other reason could be the lack of an explicit theoretical background to guide activities in Greek daycare settings. The absence of a national curriculum for childcare settings has been identified as a major concern and an indication of the status that childcare has in the Greek education system (Evangelou and Dafermou 2005). Another possible reason for the lack of developmental appropriateness of infant and toddler child care may be that infants and toddlers are generally viewed as being too young to respond to educational activities.

From Parents and Staff subscale, lowest average scores are achieved for items Provisions for parents and Opportunities for professional growth (inadequate quality). Sakellariou and Rentzou (2008) identified minimal quality when they evaluated the provision for parents and parental involvement in preschool settings. The Greek research evidence indicates that parents of children under the age of 3 ascribed more importance to care aspects like nutrition and safety aspects of settings than educational ones. An explanation seems to be more likely for Greece is that historically the kindergartens were used for educational purposes and daycare and nursery settings focused mainly on care and child protection. Another issue is that this custodial care routine does not allow for parent involvement. The studies indicated that the presence of parents was very rare and restricted to special occasions (during Christmas or Easter) (Petrogiannis 2002; Rentzou and Sakellariou 2012; Rentzou 2015; Papaprokopiou 2003). It is characteristic that the national law for childcare centers has limited references to the importance of the parental role. The item Opportunities for professional growth also has scored inadequate. Preschool educators employed at the Day Care Nurseries ran by the municipalities, under the Ministry of Internal have higher level training (university graduates), but the opportunities for continuing professional education are optional, are not centrally controlled and largely depend on the specific circumstances of each municipality.

In Greece early childhood care and education is characterized by a division between education and care services. This division reflects the country's socioeconomic and political changes (wars, poverty, and demographic changes). Socioeconomic and political influences seemed to lead settings to focus on either care or education, depending on the state's aspirations or on social demands. This history appeared to lead to a division of education and care, which is still evident today. In addition, Greece belongs to Mediterranean model, sharing a cultural emphasis on mothers' role and presence in early childhood years, strong family ties and high reliance on the extended family for supporting childcare needs (Saraceno 2000). Another issue is the lack of discussion and research studies about quality in early childhood services, combined with the absence of official evaluation procedures and inspection mechanisms, the split system of governance and the confusion of responsibilities. Since their transfer to local authorities, childcare services stopped being the concern of government. Local authorities on the other hand find it hard to make changes to childcare centers as they struggle with limited funding and their problems.

The division between early childhood education and care may not only have its roots in the history of Greek education system but it is also a reflection of how early childhood 
is understood and the relative value given by governments to policy making, funding and regulation in this field.

\section{Conclusions}

In conclusion, our results indicate that overall quality must be improved in Northern Greece daycare services for children under 3-year old. In the current economic crisis, constant flux of immigrants, demographic and sociopolitical changes, policy-makers need to base changes in early childhood care. That services need to be organized systematically with clear targets and quality orientation to provide right experiences and optimize child development.

Acknowledgements

Not applicable for that section

Declaration

The manuscript has not been published, or submitted for publication elsewhere. This manuscript is not be submitted for a special issue.

\section{Authors' contributions}

Not applicable for that section.

Funding

This research received no specific Grant from any funding agency in the public, commercial, or not-for-profit sector.

Availability of data and materials

The datasets used and/or analyzed during the current study are available from the corresponding author on reasonable request.

\section{Competing interests}

The authors declare that they have no competing interests.

Received: 17 February 2019 Accepted: 23 July 2020

Published online: 03 August 2020

\section{References}

Arnold, D., \& Doctoroff, G. (2003). The early education of socioeconomically disadvantaged children. Annual Review of Psychology, 54(1), 517-545.

Bardige, B. (2006). Infants and toddlers: Providing responsive and supportive care. Young Children, 61(4), 12.

Barros, S., \& Aguiar, C. (2010). Assessing the quality of Portuguese child care programs for toddlers. Early Childhood Research Quarterly, 25, 527-535.

Barros, S., et al. (2016). Infant child care in Portugal: Associations with structural characteristics. Early Childhood Research Quarterly, 37(1), 118-130.

Baustad, A. G. (2012). Using the Infant/Toddler Environment Rating Scale for examining the quality of care for infants and toddlers in Norwegian day care centers. Nordisk Barnehageforskning, 5(2), 1-21.

Beller, E. K., Stahnke, M., Butz, P., Stahl, W., \& Wessels, H. (1996). Two measures of the quality of group care for infants and toddlers. European Journal of Psychology of Education, 11, 151-167.

Bjørnestad, E., \& Os, E. (2018). Assessing quality in Norwegian child care for toddlers using ITERS-R. European Early Childhood Educational Research Journal, 26(1), 111-127.

Burchinal, E. (2016). Quality, thresholds, features and dosage in early care and education: Secondary data analyses of child outcomes. Monographs of the Society for Research in Child Development, 81/2.

Burchinal, R., Roberts, E., Nabors, A., \& Bryant, M. (1996). Quality of center child care and infant cognitive and language development. Child Development, 67, 606-620.

Burchinal, M., Roberts, E., Roberts, J. E., Zeisel, S. A., Hennon, E. A., \& Hooper, S. (2006). Social risk and protective child, parenting and child care factors in early elementary school years. Parenting: Science and Practice, 6(1), 79-113.

Campbell, F. A., Wasik, B. H., Pungello, E., Burchinal, M., Barbarin, O., Kainz, K., et al. (2008). Young adult outcomes of the Abecedarian and care early childhood educational interventions. Early Childhood Research Quarterly, 23, 452-466.

Cryer, D. (1999). Defining and assessing early childhood program quality. Annals of the American Academy of Political and Social Science, 563, 39-55.

Dearing, E., McCartney, K., \& Taylor, B. (2009). Does higher quality early child care promote low-income children's math and reading Achievement in middle childhood? Child Development, 80(5), 1529-1549.

Dunn, L. (1993). Proximal and distal features of day care quality and children's development. Early Childhood Research Quarterly, 8, 167-192.

European Commission/EACEA/Eurydice. (2019). Key data on early childhood education and Care in Europe-2019 Edition. Eurydice Report. Luxembourg: Publications Office of the European Union. 
European Commission/EACEA/Eurydice/Eurostat. (2014). Key data on early childhood education and care in Europe. 2014 Edition. Eurydice and Eurostat Report. Luxembourg: Publications Office of the European Union.

Evangelou, D., \& Dafermou, H. (2005). Contemporary perspectives in early childhood education. The case of Greece. In O. Saracho \& B. Spodek (Eds.), International perspectives on research in early childhood education (pp. 119-136). Greenwich: Information Age Publication.

Gevers Deynoot-Schaub, J., \& Riksen-Walraven, J. M. (2008). Infants in group care: Their interactions with professional caregivers and parents across the second year of life. Infant Behavior \& Development, 31(2), 181-189.

Ghazvini, A., \& Mullis, R. L. (2002). Center-based care for young children: Examining predictors of quality. The Journal of Genetic Psychology, 163(1), 112-125.

Goelman, H. B., Forer, P., Kershaw, G., Doherty, G., Lero, D., \& LaGrange, A. (2006). Towards a predictive model of quality in Canadian child care centers. Early Childhood Research Quarterly, 21(3), 280-295.

Harms, T., Cryer, D. R., \& Clifford, R. M. (2006). Infant toddler Environment Ratings Scale. Revised Edition. New York: Teachers College Press.

Harvard Center. (2010). Enhancing and practicing executive function skills with children from infancy to adolescence. Boston: Harvard Center.

Helburn, S. W. (Ed.). (1995). Cost, quality and child outcomes in child care centers. Technical Report. Denver: Department of Economics, Center for Research in Economic and Social Policy, University.

Helburn, S. W. \& Howes, C. (1996). Child care cost and quality. Future of Children, 6(2), 62-82 Sumer-Falls 1996.

Howes, C. (1997). Childrens experiences in center-based child care as a function of teacher background and adult: child ratio. Merrill-Palmer Quarterly, 43(3), 404-425.

Howes, C., Rodning, C., Galluzzo, D. C., \& Myers, L. (1988). Attachment and child care: Relationships with mother and caregiver. Early Childhood Research Quarterly, 3, 403-416.

Howes, C., \& Rubenstein, J. L. (1983). Determinants of toddlers' experiences in daycare: Age of entry and quality of setting. Child Care Quarterly, 14, 140-151.

Melhuish, E. (2001). The quest for quality in early day care and preschool experience continues. International Journal of Behavioral Development, 25(1), 1-6.

Melhuish, E. et al. (2015). A review of research on the effects of early childhood education and care (ECEC) upon child development. Curriculum and quality analysis impact review, CARE.

OECD. (2006). Starting Strong Il: Early childhood education and care. Paris: OECD.

OECD. (2015). Starting strong IV: Monitoring quality in early childhood education and care. Paris: OECD Publishing.

OECD. (2017). Starting strong 2017: Key OECD indicators on early childhood education and care. Paris: OECD Publishing.

Papaprokopiou, N. (2003). Public day care settings: In the Past, in the Present, In the Future. In EADAP (Ed.), Towards a cooperative and participating training in preschool education. Athens: Gutenberg. (In Greek).

Penn, H. (2011). Quality in early childhood services: An international perspective. Glasgow: Bell \& Bain Ltd.

Pessanha, M., Aguiar, C., \& Bairrāo, J. (2007). Influence of structural features on Portuguese toddler child care quality. Early Childhood Research Quarterly, 22(2), 204-214.

Petrogiannis, K. (2002). Greek day care centers' quality, caregiver's behavior and children's development. International Journal of Early Years Education, 10(2), 137-148.

Petrogiannis, K. (2013). Early education and care in Greece: In search of an identity. Nordic Early Childhood Education Research, 6(29), 1-9.

Phillipsen, L. C., Burchinal, M. R., Howes, C., \& Cryer, D. (1997). The prediction of process quality from structural features of child care. Early Childhood Research Quarterly, 12, 281-303.

Pinto, A., Pessanha, M., \& Aguiar, C. (2013). Effects of home environment and center-based child care quality on children's language, communication and literacy outcomes. Early Childhood Research Quarterly, 28, 94-101.

Plantenga, J., \& Remery, C. (2009). The provision of childcare services: A comparative review of 30 European countries. Luxembourg: Office for Official Publications of the European Communities.

Rentzou, K. (2011). Evaluating the quality of care and education provided by preschool centers. An Approach by Researcher's, Educators' and Parents' Perspectives. Unpublished Thesis. University of loannina, Greece.

Rentzou, K. (2015). Reflections on the quality of the dichotomous early education and care system in Greece. Childhood Education, 91(4), 250-258.

Rentzou, K., \& Sakellariou, M. (2012). Researchers and Parents Perspectiveson Quality of Care and Education. Early Child Development and Care, 183(2), 294-307.

Sakellariou, M., \& Rentzou, K. (2008). Evaluating provisions for parents and parental involvement in Greek Preschool Settings. The International Journal of the Humanities, 6(9), 95-106.

Saraceno, C. (2000). Being young in Italy: the paradoxes of a familistic society. European Journal of Social Quality, 2(2), $120-132$.

Slot, P. (2017). Literature review on Early Childhood Education and Care quality: Relations between structural characteristics at different levels and process quality. Internal document. Paris: $\mathrm{OECD}$.

Slot, P., Leseman, P. M., Verhagen, J., \& Mulder, H. (2015). Associations between structural quality aspects and process quality in Dutch early childhood education and care settings. Early Childhood Research Quarterly, 33, 64-76.

Smith, R., Purdon, S., Schneider, V., La Valle, I., Wollny, I., Owen, R., et al. (2009). Early Education pilot for two year old children evaluation. U.K.: Department for Children, Schools and Families.

Thomason, A., \& La Paro, K. (2009). Measuring the quality of teacher-child interactions in toddler child care. Early Education and Development, 20, 285-304

Tietze, Wolfgang, \& Cryer, Debby. (2004). Comparisons of observed process quality in German and American infant/toddler programs. International Journal of Early Years Education, 12(1), 43-62.

Tietze, W., Becker-Stoll, F., Bensel, J., Eckhardt, A. G., Haug-Schnabel, G., Kalicki, B., Keller, H., Leyendecker, B. (Hrsg.) (in Vorbereitung). (2013). NUBBEK-Nationale Untersuchung zur Bildung, Betreuung und Erziehung in der frühen Kindheit. Forschungsbericht. Weimar/Berlin: verlag das netz. 
Vandell, D. L., Belsky, J., Burchinal, M., Steinberg, L. D., Vandegrift, N., \& NICHD Early Child Care Research Network. (2010). Do effects of early child care extend to age 15 years? Results from the NICHD study of early child care and youth development. Child Development, 81(3), 737-756.

Vandell, D.L. \&Wolfe, B. (2000). Child care quality: Does it matter and does it need to be improved? Washington: Office of the Assistant Secretary for Planning and Evaluation: U.S. Department of Health and Human Services. Retrieved from http://aspe.hhs.gov

Vermeer, H., van ljzendoorn, M., De Kruif, R., Fukkink, R., Tavecchio, L., Riksen-Walraven, M., et al. (2008). Child care in the Netherlands: Trends in quality over the years 1995-2005. The Journal of Genetic Psychology, 169(4), 360-385.

Vermeer, $H_{\text {., }}$ et al. (2016). Quality of child care using the environmental rating scales: A meta-analysis of international studies. International Journal of Early Childhood, 48(1), 33-60.

von Suchodoletz, A., et al. (2017). Associations among quality indicators in early childhood education and care (ECEC) and relations with child development and learning: A meta-analysis. Internal document. Paris: OECD.

Whitebook, M., Howes, C., \& Phillips, D. A. (1989). Who cares? Child care teachers and the quality of care in America. Oakland: Child Care Employee Project.

Zachrisson, H., Lekhal, R., Toppelberg, C., \& Dearing, E. (2013). Little evidence that time in child care causes externalizing problems during Early Childhood in Norway. Child Development, 84(4), 1152-1170.

\section{Publisher's Note}

Springer Nature remains neutral with regard to jurisdictional claims in published maps and institutional affiliations.

\section{Submit your manuscript to a SpringerOpen ${ }^{\circ}$ journal and benefit from:}

Convenient online submission

- Rigorous peer review

- Open access: articles freely available online

- High visibility within the field

- Retaining the copyright to your article

Submit your next manuscript at $\boldsymbol{\Delta}$ springeropen.com 